\title{
Aspergillus fumigatus from normal and condemned carcasses with airsacculitis in commercial poultry ${ }^{1}$
}

\author{
Andréia Spanamberg ${ }^{2,3 *}$, Gustavo Machado ${ }^{4,3}$, Renata Assis Casagrande ${ }^{5,3}$, Gabriela \\ Miller Sales ${ }^{2}$, Cibele Floriano Fraga ${ }^{2}$, Luís Gustavo Corbellini ${ }^{4}$, David Driemeier ${ }^{5}$ \\ and Laerte Ferreiro ${ }^{2}$
}

\begin{abstract}
Spanamberg A., Machado G., Casagrande R.A., Sales G.M., Fraga C.F., Corbellini L.G., Driemeier D. \& Ferreiro L. 2013. Aspergillus fumigatus from normal and condemned carcasses with airsacculitis in commercial poultry. Pesquisa Veterinária Brasileira 33(9):1071-1075. Laboratório de Micologia, Faculdade de Veterinária, Universidade Federal do Rio Grande do Sul, Av. Bento Gonçalves 9090, Porto Alegre, RS 91540-000, Brazil. E-mail: andreiaspanamberg@yahoo.com.br

Carcass inspection is important for the detection of certain diseases and for monitoring their prevalence in slaughterhouses. The objective of this study was to assess the occurrence of aspergillosis caused by Aspergillus fumigatus in commercial poultry, through mycological and histopathological diagnosis, and to verify the causal association between the aspergillosis diagnosis criteria and condemnation due to airsacculitis in broilers through a case-control study. The study was carried out with 380 samples. Lungs were collected from broilers that were condemned (95) or not condemned (285) due to airsacculitis directly from the slaughter line. Forty-six (12\%) lung samples were positive for A. fumigatus in mycological culture. Among all samples, 177 (46.6\%) presented histopathological alterations, with necrotic, fibrinous, heterophilic pneumonia; heterophilic pneumonia and lymphoid hyperplasia being the most frequent. Out of the 380 lungs analyzed, $65.2 \%$ (30) showed histopathological alterations and isolation of fungi. The statistical analysis (McNemar's chi-square test) indicated a significant association between the presence of histopathological lesions and the isolation of A. fumigatus. Mycological cultivation and histopathological diagnosis increase the probability of detecting pulmonary alterations in birds condemned by the Final Inspection System, which suggests that such diagnostic criteria can improve the assessment and condemnation of birds affected by airsacculitis.
\end{abstract}

INDEX TERMS: Aspergillosis, pulmonary aspergillosis, Aspergillus fumigatus, respiratory disease, airsacculitis.

RESUMO.- [Pesquisa de Aspergillus fumigatus em carcaças de frango de corte normais e condenadas por aerossaculite.] Nos abatedouros, a inspeção das carcaças é fundamental para a detecção e monitoramento da prevalência de certas doenças. Os objetivos do trabalho foram

\footnotetext{
${ }^{1}$ Received on June 24, 2013.

Accepted for publication on July 24, 2013.

${ }^{2}$ Laboratório de Micologia, Faculdade de Veterinária (FaVet), Universidade Federal do Rio Grande do Sul (UFRGS), Avenida Bento Gonçalves 9090, Bairro Agronomia, Porto Alegre, RS 91540-000, Brazil. *Corresponding author: andreiaspanamberg@yahoo.com.br

${ }^{3}$ Programa de Pós-Graduação em Ciências Veterinárias, UFRGS, Porto Alegre, RS.

${ }^{4}$ Laboratório de Epidemiologia Veterinária, FaVet-UFRGS, Porto Alegre, RS.

${ }^{5}$ Setor de Patologia Veterinária (FaVet-UFRGS), Porto Alegre, RS.
}

avaliar a ocorrência de aspergilose causada por Aspergillus fumigatus em aves comerciais através do diagnóstico micológico e histopatológico e verificar a possibilidade de associação causal entre os critérios de diagnóstico de aspergilose e condenação por aerossaculite em frangos de corte através de um estudo de caso-controle. 0 estudo foi realizado com 380 amostras. Foram coletados pulmões de frangos condenados (95) e não condenados (285) por aerossaculite, diretamente na linha de abate de um frigorífico. Quarenta e seis (12\%) amostras de pulmão foram positivas na cultura micológica. Do total de amostras, 177 $(46,6 \%)$ apresentaram alterações histopatológicas, sendo os mais frequentes pneumonia fibrinoheterofílica necrótica, pneumonia heterofílica e hiperplasia linfóide. Do total de 380 pulmões analisados, 65,2\% (30) apresentaram al- 
terações histopatológicas e isolamento fúngico. A relação entre a presença de lesões histopatológicas e isolamento de $A$. fumigatus testada por McNemar indicou que houve associação significativa entre a presença de alterações histopatológicas e o isolamento de A. fumigatus. 0 cultivo micológico e o exame histopatológico aumentam as chances de se detectar alterações pulmonares em aves condenadas pelo Sistema de Inspeção Final do que nas aves normais, sugerindo que tais critérios de diagnóstico são eficazes para aprimorar a avaliação e condenação de aves por aerossaculite.

TERMOS DE INDEXAÇÃO: Aspergilose, aspergilose pulmonar, $A s$ pergillus fumigatus, doença respiratória, aerossaculite.

\section{INTRODUCTION}

Aspergillosis is one of the main causes of mortality in both immunocompetent and immunodepressed birds. The clinical manifestation of acute aspergillosis is usually observed in young birds, often with episodes of outbreaks in poultry farms, whereas chronic aspergillosis is more frequently observed in adult birds (Tell 2005, Charlton et al. 2008). Its clinical signs depend on the organs or systems involved. The pulmonary system is most frequently affected, with lesions observed in the air sacs and lungs of a wide variety of bird species, which leave the hosts potentially susceptible to infections by Aspergillus spp. (Charlton et al. 2008). Clinical cases of aspergillosis have already been diagnosed in chickens (Islan 2009, Ceolin et al. 2012), turkeys (Lair-Fulleringer et al. 2003), ostriches (Paixão et al. 2004), rheas (Copetti et al. 2004), penguins (Carrasco et al. 2001, Xavier et al. 2006), geese (Ziólkowska \& Tokarzewski 2007), and many other species (Cray et al. 2009, Spanamberg et al. 2012).

Aspergillosis is most frequently observed in commercial poultry, in which the disease causes stress. This stress is usually associated with poor conditions, such as inadequate ventilation and feed and poultry litter contaminated by large amounts of fungal propagules (Charlton et al. 2008). Several international studies describe the disease both in wild birds and poultry (Islan et al. 2003, Mukaratirwa 2006, Martin et al. 2007, Ziólkowska \& Tokarzewski 2007).

In slaughterhouses, carcass inspection is extremely important for the detection of certain diseases and for monitoring their occurrence, as well as for the subsequent inspection of the areas from which the batches originated. Carcass condemnation due to airsacculitis in birds is mostly caused by bacterial and/or viral diseases; however, fungi can also be the cause.

In Brazil, some studies have focused on the diagnosis of aspergillosis in newly hatched birds (Lima et al. 2001, Tessari et al. 2004, Vilela et al. 2004), as part of the sanitary monitoring of hatcheries. However, little is known about the real situation and economic impact of this mycosis in commercial farming.

The objective of this study was to assess the occurrence of aspergillosis caused by Aspergillus fumigatus in commercial poultry, through mycological and histopathological diagnosis. Additionally, this study attempted to verify the possibility of a causal association between aspergillosis diagnosis criteria and condemnation due to airsacculitis in broilers through a case-control study.

\section{MATERIALS AND METHODS}

Collection of lungs. The samples $(n=380)$ came from 56 flocks located in the State of Rio Grande do Sul, RS, Brazil. Lungs were collected from broilers that were condemned (95) or not condemned (285) due to airsacculitis and taken directly from the slaughter line of a slaughterhouse in the above state. The lungs were kept under refrigeration $\left(4^{\circ} \mathrm{C}\right)$. The evaluation and condemnation of carcasses were performed by personnel from the sanitary inspection department. All animal welfare requirements in force were observed in the slaughter process, in accordance with the respective inspection department.

Anatomopathological Diagnosis. Part of the lungs (under refrigeration) was sent for mycological examination, and the remaining part was fixed in $10 \%$ buffered formalin. These samples were then processed and stained with hematoxylin-eosin (HE) and Grocott (EasyPath ${ }^{\circledR}$ ) (Artal 2004).

Mycological diagnosis. Lung fragments were streaked onto Sabouraud Dextrose and Malt Extract Agar $\left(37-40^{\circ} \mathrm{C} / 7\right.$ days) containing chloramphenicol for the isolation of Aspergillus spp. The fungal isolates were picked onto Czapeck-Dox agar for final macroscopic and microscopic identification of the species (Stevens 2002).

Definition of cases and controls. The lungs of birds condemned due to airsacculitis were defined as "case", and the lungs obtained from normal birds from the same batch were defined as "control". In airsacculitis, total condemnation occurs when widespread lesions are observed in the carcass (emaciation or cachexia), and partial condemnation occurs when the carcass is not impaired (the legs, wings and breast can be used).

Calculation of sample sizes. The size of the samples was calculated for an unmatched case-control study, corrected by the Kelsey method (Kelsey et al. 1996). The study was planned for the identification of the odds ratio, with a magnitude of 2 and a power of $80 \%$ at a $95 \%$ significance level (Kelsey et al. 1996):

and

$$
\frac{\mathrm{n} 1=\left(\mathrm{Z}_{\alpha / 2} \pm \mathrm{Z}_{1-\beta}\right)^{2} \overline{\mathrm{pq}}(\mathrm{r} \pm 1)}{\mathrm{r}\left(\mathrm{p}_{1}-\mathrm{p}_{2}\right)^{2}}
$$

$$
\mathrm{n}_{2}=\mathrm{rn}_{1}
$$

where $n_{1}=$ number of exposures; $n_{2}=$ number of non-exposures; $\mathrm{Z}_{\alpha / 2}=$ normal standard deviation for the two-tailed test, based on the alpha level; $\mathrm{Z}_{\beta}=$ normal standard deviation for the one-tailed test, based on the beta level; $r=$ ratio of non-exposures in relation to the exposures; $p_{1}=$ proportion of exposures with the disease and $\mathrm{q}_{1}=1-\mathrm{p}_{1}, \mathrm{p}_{2}=$ proportion of non-exposures with the disease and $\mathrm{q}_{2}=1-\mathrm{p}_{2}$.

The minimum sample for this purpose was 95 cases and 285 controls. The study considered an $m: n$ (1:3) rate of cases and controls. The independent variables were first analyzed for data consistency. Variables with missing values $(>10 \%)$ or with variability $(<20 \%)$ were not considered for later analysis.

Statistical analysis. The data were stored in Excel spreadsheets and analyzed by descriptive statistics, frequency distribution and contingency tables. McNemar's chi-square test was used to assess the association between the presence of histopathological lesions and the isolation of Aspergillus fumigatus.

All analyses were made in R (packagedEpiCalc) and SAS (version 9.2; SAS Institute Inc., Cary, NC, USA). Logistic regression was used to verify the relation between the dependent variable (cases 
- presence of airsacculitis/with carcass condemnation; and controls - absence of airsacculitis/without carcass condemnation) and the independent variables (HE microscopic alterations; macroscopic alterations, mycological results and Grocott staining) (Hosmer \& Lemeshow 2000).

The remaining variables were individually analyzed by logistic regression, and those with $\mathrm{p}<0.15$ were selected. Then, all va-

Table 1. Results of mycological culture for Aspergillus fumigatus

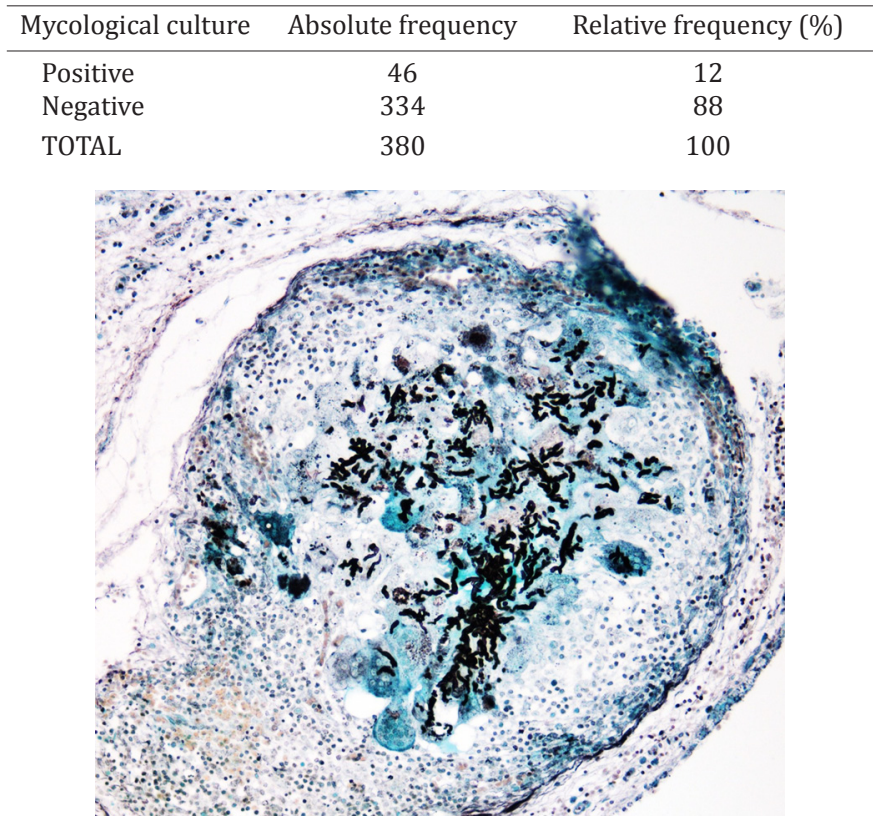

Fig.1. Hyaline, branching septate hyphae of Aspergillus fumigatus. Grocott staining, obj.20x. riables with $p<0.15$ were submitted to correlation analysis (with $r=0.70$ being critical). The remaining variables were studied using the multivariable model, constructed manually forward and with backward elimination of those variables with $\mathrm{p}>0.05$. The control for confounding variables was verified by monitoring the alterations in the estimator values. The discriminatory power of the model was measured by the area under the ROC curve, and the adjustment verification of the model was made by the Hosmer and Lemeshow test (Hosmer \& Lemeshow 2000).

\section{RESULTS}

Forty-six (12\%) lung samples were positive for Aspergillus fumigatus in mycological culture (Table 1). These isolates came from 23 flocks located in different counties.

Among all samples, 177 (46.6\%) presented histopathological alterations, among which the most frequent were necrotic, fibrinous, heterophilic pneumonia, heterophilic pneumonia and lymphoid hyperplasia (Table 2). Only in one sample were fungal elements detected by $\mathrm{HE}$ and Grocott staining (Fig. 1). Fifty-nine (15.52\%) lung samples showed macroscopic alterations.

Of the 380 lungs analyzed, 65.2\% (30) showed histopathological alterations and isolation of fungi (Table 3). The statistical analysis (McNemar's chi-square test, $\chi^{2}=7,28$ / $p<0,05$ ) indicated a significant association between the presence of histopathological lesions and the isolation of $A$. fumigatus. Additionally, A. fumigatus was 2.3 times more likely to be isolated in animals with histopathological lesions than in those with no lesions. The logistic regression model identified a significant association of the following assays with condemnation due to airsacculitis (i.e., cases): mycological culture $\left(\mathrm{OR}=11,17 ; \mathrm{CI}_{95 \%}=4,17-30,27 ; p<0,001\right)$

Table 2. Frequency of histopathological alterations (HE staining) in lung samples

\begin{tabular}{lcccc}
\hline \multirow{2}{*}{ Histopathologic diagnosis } & \multicolumn{2}{c}{ Lesion intensity } & Total \\
\cline { 2 - 3 } & Mild & Moderate Severe & \\
\hline Fibrinous heterophilic bronchopneumonia & 0 & 1 & 2 & 3 \\
Necrotic fibrinous heterophilic bronchopneumonia & 0 & 1 & 1 & 2 \\
Fibrinous heterophilic bronchitis & 0 & 3 & 3 & 6 \\
Necrotic fibrinous heterophilic bronchitis & 3 & 2 & 0 & 5 \\
Heterophilic bronchitis & 3 & 0 & 2 & 5 \\
Chronic pleuritis & 1 & 1 & 0 & 2 \\
Fibrinous heterophilic pleuropneumonia & 0 & 1 & 0 & 1 \\
Necrotic fibrinous heterophilic pleuropneumonia & 0 & 0 & 2 & 2 \\
Fibrinous heterophilic pneumonia & 1 & 6 & 1 & 8 \\
Necrotic fibrinous heterophilic pneumonia & 0 & 6 & 11 & 17 \\
Granulomatous pneumonia & 0 & 1 & 0 & 1 \\
Heterophilic pneumonia & 13 & 2 & 0 & 15 \\
Lymphoid hyperplasia & 107 & 22 & 1 & 130 \\
Normal & & & & 203 \\
TOTAL & & & & 380
\end{tabular}

Table 3. Histopathological results (HE staining) and Aspergillus fumigatus isolation

\begin{tabular}{lcccc}
\hline $\begin{array}{l}\text { Mycological } \\
\text { culture }\end{array}$ & \multicolumn{4}{c}{ Histopathology (HE) } \\
\cline { 2 - 5 } & $\begin{array}{c}\text { With } \\
\text { alterations }\end{array}$ & $\begin{array}{c}\text { Without } \\
\text { alterations }\end{array}$ & Total & $\begin{array}{c}\text { Relative } \\
\text { frequency (\%) }\end{array}$ \\
\hline Positive & $30^{*}$ & 16 & 46 & 65,2 \\
Negative & 147 & 187 & 334 & 44 \\
TOTAL & 177 & 203 & 380 & 46,6
\end{tabular}

* Detection of fungal elements (Grocott staining): hyaline, branching septate hyphae $(\mathrm{n}=1)$.
Table 4. Multivariate logistic regression analysis between mycological cultures and histopathology results

\begin{tabular}{lcccc}
\hline \multicolumn{1}{c}{ Variable } & Estimate $(\beta)$ & $\begin{array}{c}\text { Standard } \\
\text { error }\end{array}$ & $p$-value & Odds (CI: 95\%) \\
\hline $\begin{array}{l}\text { Mycological culture } \\
\text { Positive }\end{array}$ & 2.41 & 0.50 & $<0.001$ & $11.17(4.17-30.27)$ \\
$\quad \begin{array}{l}\text { Negative } \\
\text { Histopathology (HE) }\end{array}$ & - & - & - & - \\
$\begin{array}{l}\text { With alterations } \\
\text { Without alterations }\end{array}$ & 1.26 & 0.29 & $<0.001$ & $3.53(1.97-6.32)$ \\
& - & - & - & -
\end{tabular}


and histopathological testing (OR $=3,53 ; \mathrm{CI}_{95 \%}=1,97-6,32$; $p<0,001$ ) (Table 4). The discriminatory power of the model identified by the ROC curve was $70 \%$, and the adequacy of the model was verified using the Hosmer-Lemeshow test $(\mathrm{p}=0.80)$.

\section{DISCUSSION}

The widespread distribution of fungal propagules with tiny diameters, particularly in the case of Aspergillus fumigatus, which is found on the anemophilous flora of all continents, constantly exposes the respiratory tract of both humans and animals to fungal colonization.

Tashiro et al. (2011) observed a fungal colonization rate of 45\% (62) in 139 human lungs, with A. fumigatus being the most frequently isolated fungus (41\%). Similarly, Lass-Flörl et al. (1999) found that A. fumigatus prevailed in $41.07 \%$ of 74 positive samples.

In broilers under suspicion of aspergillosis, Sajid et al. (2006) and Islan et al. (2003) isolated A. fumigatus in $48.43 \%$ and $17.53 \%$ of the cultures, respectively. In this study, 46 (12\%) of the lungs analyzed contained A. fumigatus. Specifically in the case of birds, conditions that favor the development of fungi in confinement buildings expose commercial poultry to a higher risk of inhaling conidia of A. fumigatus during the farming period. This is a condition that frequently results in the isolation of the fungus from the lungs of healthy birds (Arné et al. 2011).

Even though only one case was clearly characterized as aspergillosis through histopathological testing and mycological cultivation, we verified that there was a significant association between the two variables. The literature shows that in some cases, cultures of fungi and cytopathological examination of respiratory specimens often yield negative results and a lack sensitivity for detecting fungal elements in an early stage of infection (Tarrand et al. 2003). Aspergillus fumigatus is also frequently isolated from straw and straw particles in animal housing for pigs, cattle and poultry, where repeated exposure can cause outbreaks of invasive disease in poultry flocks and respiratory problems in other animals (Arné et al. 2011). Among animals that are affected by aspergillosis, birds are among the species that can naturally acquire infection in the absence of immunodepression (Clemons \& Stevens 2005).

A small number of samples with macroscopic alterations $(15.52 \%)$ was found in the study. In a study of the anatomopathological aspects of aspergillosis in birds, Cacciuttolo et al. (2009) suggest that the presence of conidia in their respiratory system may lead to a latent infection without clinical symptoms and macroscopic lesions. Recovery of Aspergillus spp. in respiratory samples in the absence of signs of pneumonia suggests that birds may only be carriers of the fungi unless stimulated by a decreased resistance of the host elicited by some stress such as an infectious disease, a toxin or malnutrition (Garcia et al. 2007).

Respiratory infections are common among the chicken population. The histopathological diagnosis of the lung sections showed several alterations in $46,6 \%$ of the samples (lymphoid hyperplasia, pneumonia, bronchitis and bronchopneumonia) with variable lesion intensity most likely associated with bacterial and/or viral agents (Zafra et al. 2008). However, our results concur with the findings of Steinlage et al. (2003), which indicate that A. fumigatus may not be the primary cause of respiratory infection. The histological alteration observed most frequently was lymphoid hyperplasia. This change is often nonspecific and quite frequently occurs in the respiratory system in response to any injury (Fletcher 2008).

Regarding the logistic regression results, it is possible to suggest that both the mycological cultivation and the histopathological testing increase the probability of detecting pulmonary alterations in birds condemned by the Final Inspection System, which suggests that such diagnostic criteria can improve the assessment and condemnation of birds affected by airsacculitis. Fungal isolation from respiratory samples has been regarded as being of limited usefulness in the ante mortem diagnosis of aspergillosis in human patients. However, in livestock, this is a widely used tool for monitoring batches and may point to possible corrective measures for risk factors found in the properties in question.

Acknowledgements.- Financial support was received from Fundação de Amparo à Pesquisa do Estado do Rio Grande do Sul (FAPERGS) and from Conselho Nacional de Desenvolvimento Científico e Tecnológico (CNPq). The authors thank Everton Fauth of the Federal Inspection Service, RS, for access to the data presented in this study.

\section{REFERENCES}

Arné P., Thierry S., Wang D., Deville M., Le Loc'h G., Desoutter A., Féménia F., Nieguitsila A., Huang W., Chermette R. \& Guillot J. 2011. Aspergillus fumigatus in Poultry. Int. J. Microbiol. Article ID 746356. Doi:10.1155/2011/746356. 14p.

Artal E.M. 2004. Diagnóstico histopatológico de las micosis. Revta Iberoam. Micol. 21:1-9.

Cacciuttolo E., Rossi G., Nardoni S., Legrottaglie R. \& Mani P. 2009. Anatomopathological aspects of avian aspergillosis. Vet. Res. Commun. 33:521-527.

Carrasco L., Lima J.S., Halfen D.C., Salguero F.J., Sanchez-Cordon P. \& Becker G. 2001. Systemic aspergillosis in an oiled magallanic penguin (Spheniscus magellanicus). J. Vet. Med. B, Infect. Dis. Vet. Public Health 48:551554.

Ceolin L.V., Flores F., Oliveira I.M.C., Lovato M., Galiza G.J.N., Kommers G.D., Risso N. \& Santurio J.M. 2012. Macroscopic and Microscopic Diagnosis of Aspergillosis in Poultry. Acta Scient. Vet. 40(3):1061.

Charlton B.R., Chin R.P. \& Barnes H.J. 2008. Fungal infections, p.9891001. In: Saif Y.M., Fadly A.M., Glisson J.R., McDougald L.R., Nolan L.K. \& Swayne D.E. (Eds), Diseases of Poultry. Blackwell Publishing. Ames, Iowa.

Clemons K.V. \& Stevens D.A. 2005. The contribution of animal models of aspergillosis to understanding pathogenesis, therapy and virulence. Med. Mycol. 43(1):S101-S110.

Copetti M.V., Segabinazi S.D., Flores M.L., Alves S.H. \& Santurio J.M. 2004. Pulmonary aspergillosis outbreak in Rhea americana in Southern Brazil. Mycopathologia 157:269-271.

Cray C., Watson T. \& Arheart K. 2009. Serosurvey and diagnostic application of antibody titers to Aspergillus in avian species. Avian Dis. 53:491494.

Fletcher O.J. 2008. Avian Histopathology. $3^{\text {rd }}$ ed. Omni Press, Madison. 438p.

Garcia M.E., Lanzarot P., Rodas V.L., Costas E., J.L. \& Blanco. 2007. Fungal flora in the trachea of birds from a wildlife rehabilitation centre in Spain. Vet. Med.-Czech. 52(10):464-470. 
Hosmer D.W. \& Lemeshow S. 2000. Applied Logistic Regression. Wiley, New York. 392p.

Islan M.N., Rashid M.H., Juli M.S.B., Rima U.K. \& Khatun M. 2009. Pneumomycosis in chickens: clinical, pathological and therapeutical investigation. Int. J. Sustain. Crop Prod. 4:16-21.

Islan M.R., Das B.C., Hossain K., Lucky N.S. \& Mostafa M.G. 2003. A study on the occurrence of poultry diseases in Sylhet region of Bangladesh. Int. J. Sustain. Crop Prod. 2:354-356.

Kelsey J.L. 1996. Methods in Observational Epidemiology. $2^{\text {nd }}$ ed. Oxford University Press, New York. 432p.

Lair-Fulleringer S., Guillot J., Desterke C., Seguin D., Warin S., Bezille A., Chermette R. \& Bretagne S. 2003. Differentiation between isolates of Aspergillus fumigatus from breeding turkeys and their environment by genotyping with microsatellite markers. J. Clin. Microbiol. 41:17981800.

Lass-Flörl C., Salzer G.M., Schmid T., Rabl W., Ulmer H. \& Dierichi M.P. 1999. Pulmonary Aspergillus colonization in humans and its impact on management of critically ill patients. Brit. J. Haematol. 104(4):745-747.

Lima Jr J.S., Pinto D.M., Carrasco L.O., Salgueiro F.J.B. \& Meireles M.C.A. 2001. Incidência de fungos na produção de pintos de corte de um dia de idade. Revta Bras. Agrociência 7:73-77.

Martin M.P., Bouck K.P., Helm J., Dykstra M.J., Wages D.P. \& Barnes J. 2007. Disseminates Aspergillus flavus infection in broiler breeder pullets. Avian Dis. 51:626-631.

Mukaratirwa S. 2006. Outbreak of disseminated zygomycosis and concomitant pulmonary aspergillosis in breeder layer cockerels. J. Vet. Med. 53:51-53.

Paixão T.A., Nascimento E.F., Parra P.N.S. \& Santos R.L. 2004. Aspergilose em avestruz (Struthio camelus) no Brasil. Ciência Rural 34:573-576.

Sajid M.A., Khan I.A. \& Rauf U. 2006. Aspergillus fumigatus in commercial poultry flocks, a serious threat to poultry industry in Pakistan. J. Anim. Plant Sci. 16:79-81.

Spanamberg A., Casagrande R.A., Ferreiro L., Rolim V.M., Souza S.O., Gonçalves I.C.M., Oliveira L.G.S., Wouters F., Wouters A.T.B., Fontana C.S.
\& Driemeier D. 2012. Aspergillosis in green-winged saltators (Saltator similis) participants in bird singing competitions. Acta Scient. Vet. 40(4):1089.

Steinlage S.J.T., Sander J.E., Brown T.P., Lobsinger C.M., Thayer S.G. \& Martinez A. 2003. Disseminated mycosis in layer cockerels and pullets. Avian Dis. 47:229-233.

Stevens D.A. 2002. Diagnosis of fungal infections: current status. J. Antimicrob. Chemother. 49:11-19.

Tarrand J.J., Lichterfeld M., Warraich I., Luna M., Han X.Y., May G.S. \& Kontoyiannis D.P. 2003. Diagnosis of invasive septate mold infections. A correlation of microbiological culture and histologic or cytologic examination. Am. J. Clin. Pathol. 119:854-858.

Tashiro T., Izumikawa K., Tashiro M., Takazono T., Morinaga Y., Yamamoto K., Imamura Y., Miyazaki T., Seki M., Kakeya H., Yamamoto Y., Yanagihara K., Yasuoka A. \& Kohno S. 2011. Diagnostic significance of Aspergillus species isolated from respiratory samples in an adult pneumology ward. Med. Mycol. 49:581-587.

Tell L.A. 2005. Aspergillosis in mammals and birds: impact on veterinary medicine. Med. Mycol. 43:71-73.

Tessari E.N.C., Cardoso A.L.S.P., Castro A.G.M., Kanashiro A.M.I. \& Zanatta G.F. 2004. Prevalência de aspergilose pulmonar em pintos de um dia de idade. Arqs Inst. Biológico, São Paulo, 71:75-77.

Vilela S.M.O., Mota R.A., Santos A.P.F., Silva L.B.G. \& Silva J.S.A. 2004. Surto de Aspergilose ocular em pintos de corte (Gallus gallus domesticus Linneaus, 1758). Ciênc. Vet. Tróp. 7:145-147.

Xavier M.O., Leite A.T.M. \& Soares M.P. 2006. Aspergilose em pinguim-de-Magalhães (Spheniscus magellanicus) - relato de caso. Vet. Zootec. 13:28-32.

Zafra R., Pérez J., Pérez-Écija R.A., Borge C., Bustamante R., Carbonero A. \& Tarradas C. 2008. Concurrent aspergillosis and ascites with high mortality in a farm of growing broiler chickens. Avian Dis. 52:711-713.

Ziólkowska G. \& Tokarzewski S. 2007. Occurrence of moulds in reproductive goose flocks in southern-eastern Poland. Bull. Vet. Inst. Pulawy 51:553-561. 